\section{Paul Graham - det sociale landskabs fotograf}

\author{
af freelance kurator Tone O. Nielsen
}

I Det Kongelige Biblioteks Kort- og Billedafdeling findes adskillige værker af den engelske fotograf Paul Graham (f. 1956), og samlingen er netop blevet udvidet med endnu et værk, nemlig den fotografiske triptykon bestående af farvefotografierne "Mariko", "Toyota Engine \#2 (Celsior)" og "Rie", som alle er optaget i hovedstaden Tokyo i perioden 1989-95.

Paul Graham har op i gennem 80 'erne og 90 'erne markeret sig som en af de ledende skikkelser inden for yngre europxisk fotografi, og han er ofte er blevet kaldt det sociale landskabs fotograf. ${ }^{1}$ Siden midten af 80'erne har Graham rejst det meste af den Første Verden rundt med ønsket om at registrere den samfundsmæssige tilstand $\mathrm{i}$ en lang række velstillede lande og har udviklet en helt egen fotografisk form, der på én gang både dokumenterer og kommenterer den sociale, politiske, økonomiske og kulturelle situation i de pågældende lande. Til Grahams kendeste projekter hører således hans fotografiske serie fra en række af Englands bistandskontorer og serierne "Troubled Land" 2 og "New Europe"3 optaget i henholdsvis Nordirland og Tyskland, Schweiz, Italien, Spanien, Frankrig, Belgien og Holland i perioden før og efter Murens Fald.

Grahams fotografi kan således karakteriseres som værende socialt og samfundsmæssigt engageret. Men skønt han med-sit kamera forsøger at indfange specifikke sociale, politiske, økonomiske, hi- storiske og religiøse begivenheder, der har haft efterladt sig mærkbare spor i det sociale og politiske landskab og hos det moderne menneske, adskiller hans fotografi sig dog voldsomt fra det traditionelle dokumentariske fotografi, som vi kender det fra bl.a. medierne, såvel motivisk som formelt. For Graham begiver sig ikke ud i "krigszonen" for at komme helt tæt på begivenhederne eller personerne og indfange det dramatiske og sensationelle øjeblik. Faktisk er der sjældent handling i hans billeder. Rigtigere er det at sige, at Graham fotograferer sporerne eller tegnene efter begivenhederne; alle de "skjulte" tegn og betydningsbærende billeder, der omgiver os $\mathrm{i}$ vores hverdag, og som vidner om specifikke historiske forløb. Tegn, som vi alt for ofte overser, men som ikke desto mindre er spor af en udvikling, der til stadighed præger vor adfærd og levevis. Når disse tegn forstørres fotografisk og sættes sammen to og to eller i grupper på tre, făr vi pludselig øje for deres betydninger.

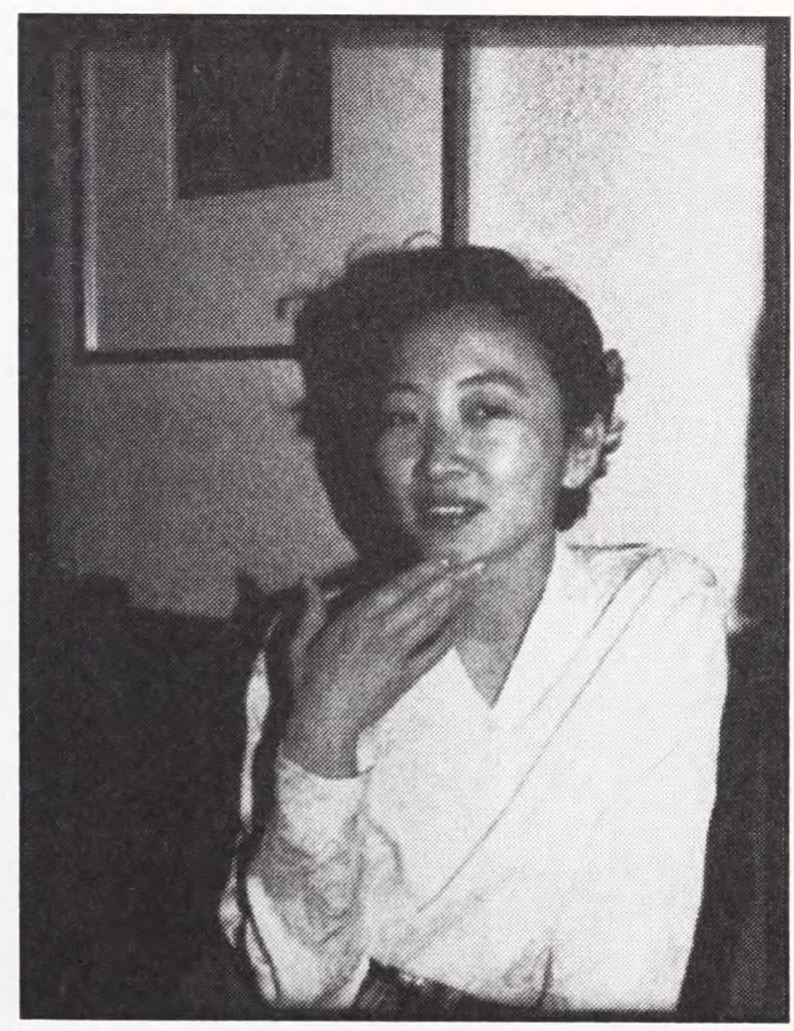


I den triptykon, som Kort- og Billedafdelingen for nylig har erhvervet, får portættet af den unge japanske kvinde Mariko i et vestligt lignende interiør i Tokyo således en ny betydning, når det sammenkobles med fotografiet af en topmoderne Toyota-motor. Bilmotoren bliver et symbol på Japans bemærkelsesværdige teknologiske udvikling efter 2 . Verdenskrig, der har fremskabt en ny generation af moderne kvinder, som ikke længere er anonyme og tilbageholdende i overensstemmelse med de traditionelle kønsroller i Japan, men er aktive aktører i samfundslivet. Forbindelsen mellem den moderne japanske kvinde anno 1989 og Japans modernisering er således etableret. Når disse betydninger igen sammenstilles med det tredje fotografi af en anden ung japansk kvinde ved navn Rie, som opholder sig i et traditionelt japansk hus med tatami-måtter på gulvet og rispapirsskydedøre i baggrunden, henledes tanken på den japanske tradition og kulturarv, som Japans yngre generationer bevæger sig stadig længere og længere væk fra. Koder strømmer således fra det ene fotografi til det andet, og et kompliceret netværk af betydninger opstår.

Med denne fotografiske form lykkes det ikke bare Graham at registrere det sociale landskabs overflade, men også dets dybde. På én og samme tid indfanger Graham det ydre, materielle landskab og de indre, sociale og kulturelle strukturer. Den fotografiske brug af diptykoner eller triptykoner betyder, at udviklingen eller begivenhederne ikke længere ses isoleret fra en større kontekst, men at konflikternes mangesidede og komplekse natur træder frem. Ligeledes forstærker fotografiernes næsten skulpturelle fremtoning og righoldige farvepalet den psykologiske oplevelse. Dermed undgår Graham at blive den moraliserende, dømmende, reporterende eller partiske fotograf, som fortolker og forenkler virkeligheden. Graham udlægger virkeligheden set fra mange for-

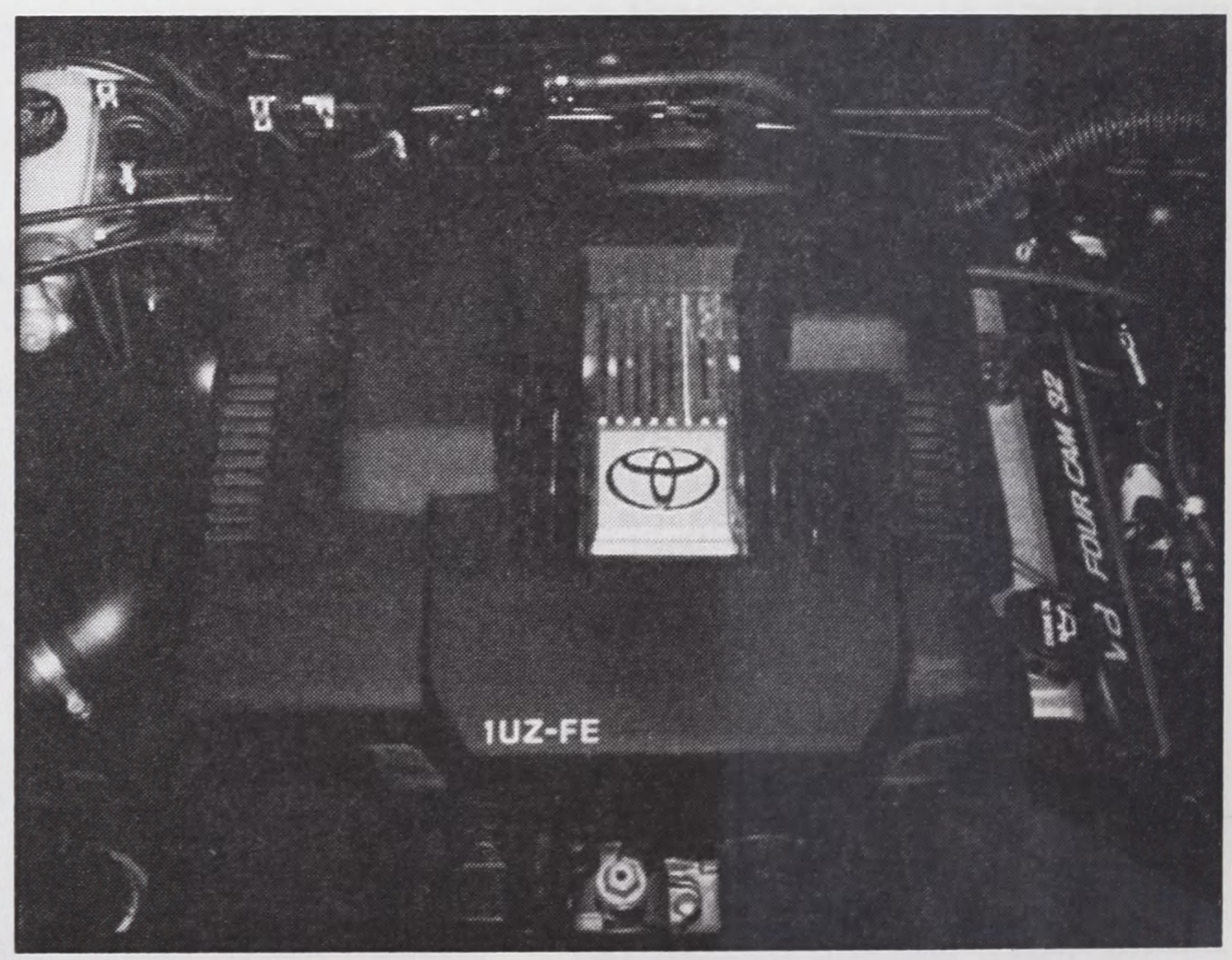


skellige synsvinkler, og de mange betydningslag i hans arbejder står derfor i skarp kontrast til vor tids ekspanderende billedverden og den følelsesafstumpning, som denne stadige billedstrøm har medført.

Noter

1 Declan McGonagle and Gerry Badger, Troubled Landscape. The Social Landscape of Northern Ireland. Photographs by Paul

Graham, Grey Editions, London 1987.

2 McGonagle and Badger, op.cit..

3 Paul Graham. New Europe, Fotomuseum Winterthur and Cornerhouse Publications, Schweiz and Manchester 1993.

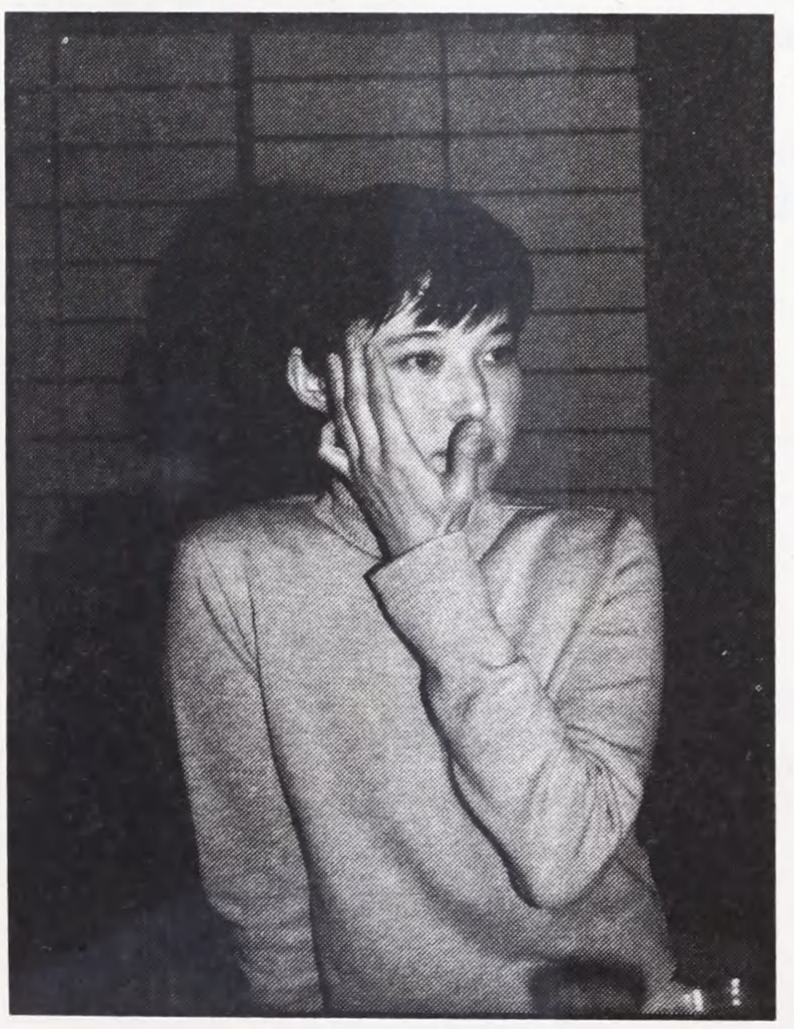

